\title{
Metabolic syndrome, lipoprotein(a) and subclinical atherosclerosis in Mexican population
}

\section{Síndrome metabólico, lipoproteína(a) y aterosclerosis subclínica en población mexicana}

\author{
Guillermo C. Cardoso-Saldaña ${ }^{*}$, María del C. González-Salazar , Rosalinda Posadas-Sánchez, \\ and Gilberto Vargas-Alarcón ${ }^{2}$ \\ ${ }^{1}$ Department of Endocrinology; ${ }^{2}$ Department of Molecular Biology. Instituto Nacional de Cardiología Ignacio Chávez, Mexico City, Mexico
}

\begin{abstract}
Objective: To assess the relationship of metabolic syndrome (MetS) and $L p(a)$ with subclinical atherosclerosis (CAC) in Mexican adults. Method: Clinical, biochemical and tomographic data of visceral, subcutaneous, hepatic abdominal fat and CAC were evaluated in 953 women and men. $L p(a)$ was determined by nephelometry and MetS was diagnosed according to ATP III criteria. Multivariate logistic regression analysis was performed to determine the independent association of these variables with CAC. Results: Age, weight, body mass index, systolic and diastolic blood pressure, volumes of visceral, subcutaneous and hepatic abdominal fat, lipids, glucose, insulin and HOMA-RI were significantly higher in subjects with MetS. The median $L p(a)$ was lower in subjects with MetS compared to subjects without MetS (3.7 [IR: 2.3-9.2 vs. 5.9 [IR: 2.5-13.1) $\mathrm{mg} / \mathrm{dL} ; p<0.01)$. The number of components and the MetS were inversely associated with the elevated $L p(a)$ (>30 mg / dL). The presence of MetS was associated with a CAC risk >0 (OR: 2.19, [95\% Cl (1.64-2.94)]; $p<0.001)$, independently of elevated $L p(a)$. The components of MetS that were independently associated with the presence of CAC $>0$ UA were glycaemia > $100 \mathrm{mg} / \mathrm{dL}$ (OR 2.42, [95\% Cl (1.7-3.4)]; $p<0.0001)$ and high blood pressure (OR 2.14 [95\% $\mathrm{Cl}(1.5-3.1)] ; p<0.0001)$. Conclusions: In Mexican population there is an inverse association between $L p(a)$ levels and MetS. The MetS and its components were associated with subclinical atherosclerosis. The high prevalence of obesity, diabetes, high blood pressure high triglycerides and low HDL-C, characteristics of Mexican population could explain the differences with other populations.
\end{abstract}

Key words: Subclinical atherosclerosis. Lipoprotein (a). Metabolic syndrome.

\section{Resumen}

Objetivo: Investigar la asociación del síndrome metabólico y la lipoproteína(a) $[L p(a)]$ con el riesgo de aterosclerosis subclínica en adultos mexicanos. Método: En 953 mujeres y hombres se evaluaron datos clínicos, bioquímicos y tomográficos de grasa abdominal visceral, subcutánea, hepática y calcio arterial coronario. La Lp(a) se determinó mediante nefelometría y el síndrome metabólico se diagnosticó con los criterios del Adult Treatment Panel III. La asociación independiente de estas variables con el calcio arterial coronario se obtuvo con análisis de regresión logística multivariada. Resultados: La edad, el peso, el índice de masa corporal, la presión arterial sistólica y diastólica, los volúmenes de grasa abdominal, los lípidos, la

\section{Correspondence:}

*Guillermo C. Cardoso-Saldaña

E-mail: gccardosos@yahoo.com license (http://creativecommons.org/licenses/by-nc-nd/4.0/).

Date of reception: 11-06-2020

Date of acceptance: $28-10-2020$

DOI: 10.24875/ACME.M21000222
Available online: $20-10-2021$ Arch Cardiol Mex (Eng). 2021;91(3):274-281 www.archivoscardiologia.com 
glucosa, la insulina y el índice de resistencia a insulina fueron significativamente mayores en los sujetos con síndrome metabólico, mientras que la mediana de $L p(a)$ fue más baja en comparación con los sujetos sin el síndrome (3.7 [rango intercuartílico (RIC): 2.3-9.2 vs. 5.9 [RIC: 2.5-13.1) $\mathrm{mg} / \mathrm{dl} ; p<0.01)$. El número de componentes y el síndrome metabólico se asociaron inversamente con la $L p(a)$ elevada (> $30 \mathrm{mg} / \mathrm{dl}$ ). La presencia de síndrome metabólico se asoció con un riesgo de calcio arterial coronario > 0 (odds ratio [OR]: 2.19; intervalo de confianza del 95\% [IC95\%]: 1.64-2.94; $p<0.001$ ), independientemente de la Lp(a) elevada. La glucemia > 100 mg/dl (OR: 2.42; IC95\%: 1.7-3.4; $p<0.0001)$ y la presión arterial elevada (OR: 2.14; IC95\%: 1.5-3.1; $p$ > 0.0001) se asociaron con calcio arterial coronario > 0. Conclusiones: En población mexicana existe una asociación inversa entre la concentración de $L p(a)$ y el síndrome metabólico. Este y sus componentes se asociaron positivamente con aterosclerosis subclínica. La elevada prevalencia de obesidad, diabetes, hipertensión arterial, triglicéridos elevados y concentración de colesterol unido a lipoproteínas de alta densidad que caracterizan a la población mexicana pudieran explicar las diferencias con otras poblaciones.

Palabras clave: Aterosclerosis subclínica. Lipoproteína (a). Síndrome metabólico.

\section{Introduction}

Metabolic syndrome (MetS) is characterized by insulin resistance, excess weight, glucose intolerance, atherogenic dyslipidemia (elevated triglycerides and low high-density lipoprotein cholesterol [HDL-C]), inflammation and pro-thrombotic state ${ }^{1,2}$. Retrospective clinical trials and meta-analyses have shown that patients with MetS are at increased risk of coronary artery disease $(C A D)^{3,4}$. Lipoprotein(a) $[L p(a)]$ is a macromolecular complex formed by a low-density lipoprotein and Apo(a), a protein similar to plasminogen ${ }^{5}$ that binds to fibrin and thus blocks fibrinolysis and increases thrombogenesis ${ }^{6,7}$. Several studies have shown that $L p(a)$ elevated concentration is an independent risk factor for $C A D^{8-13}$. However, the association with calcium buildup on coronary arteries is controversial: some evidences are positive ${ }^{14,15}$ and others are negative ${ }^{16,17}$. The inconsistency of results could be mainly due to: 1 ) the wide variation in $L p(a)$ concentration, which is genetically determined in ethnic groups; 2) the prevalence of LPA gene polymorphisms associated with $L p(a)$ elevated concentrations ${ }^{18-20}$; and 3) differences in the prevalence of obesity, diabetes, hypertension and smoking in the studied groups. According to the 2018 National Survey on Health and Nutrition (https://ensanut.insp. $\mathrm{mx} /$ encuestas/ensanut2018/informes.php) in the Mexican adult population, the prevalence of MetS is $45 \%$; that of excess weight (overweight and obesity), $75.2 \%$; of diabetes mellitus, $10.3 \%$; hypertension, $18.4 \%$; and that of smoking is $7.1 \%$. In a previous study in the Mexican population, the prevalence of elevated $L p(a)$ $\geq 30 \mathrm{mg} / \mathrm{dL}$ was $14 \%$, and in $33 \%$ of patients with CAD, it was associated with acute myocardial infarction $^{21}$. In a study in Mexican mestizos with no personal or family history of CAD, the prevalence of coronary artery calcification $(\mathrm{CAC})>0$, which is an independent risk factor for $C A D^{22}$, was $27 \%{ }^{23}$.

Considering that the prevalence of both MetS and $\mathrm{L}(\mathrm{a}) \geq 30 \mathrm{mg} / \mathrm{dL}$ is high in our population, and that the effect of the coexistence of both risk factors on subclinical atherosclerosis is unknown, the purpose of this study was to investigate, in subjects without personal or family history of CAD, the association of MetS and $L p(a)$ concentration with the presence of subclinical atherosclerosis as assessed by CAC.

\section{Method}

\section{Study subjects}

953 subjects participating in the Atherosclerotic Disease Genetics (GEA - Genética de la Enfermedad Ateroesclerosa) project ${ }^{24}$, designed at Ignacio Chávez National Institute of Cardiology, were included in order to investigate the association of genetic factors with traditional and emerging cardiovascular risk factors in an adult Mexican population of Mexico City with no history of premature CAD, with an age between 35 and 70 years, in subjects recruited among donors who attend the blood bank of said Institute or by invitation in health centers of the metropolitan area of Mexico City. None of the participants had liver, kidney, thyroid or oncological disease. The study protocol was approved by the Ethics Committee of the National Institute of Cardiology and designed according to the guidelines of the Declaration of Helsinki. All participants signed an informed consent document.

Validated questionnaires were applied to all subjects in order to obtain demographic information, personal and family history of risk factors for $C A D$, physical activity and medication use. The body mass index (BMI) was obtained with the following formula: weight $(\mathrm{kg}) /$ 
height $\left(\mathrm{m}^{2}\right)$. The waist circumference $(\mathrm{cm})$ was measured with a fiberglass measuring tape, placed on the midpoint between the last rib and the iliac crest, with a 0.5-cm approximation.

Heart rate and systolic and diastolic blood pressure were measured three times with 1-minute intervals, after 10 minutes of rest in a sitting position. For statistical analyses, average of the second and third measurements was used. Hypertension was defined according to the Seventh Report of the Joint National Committee on Prevention, Detection, Evaluation and Treatment of High Blood Pressure guidelines ${ }^{25}$. Subjects who smoked at least one cigarette a day or seven per week within 6 months prior to the study were considered active smokers. Physical activity during work and free time was assessed using an internationally-validated questionnaire ${ }^{26}$.

Participants' blood samples were obtained in the morning after a fast of at least 10 hours, without having practiced exercise before the venous puncture and after 20 minutes at rest in a sitting position. Glucose, total cholesterol (TC), triglycerides (TG), HDL-C, $\mathrm{Apo} \mathrm{Al}$ and $\mathrm{B} 100$ plasma values were determined with colorimetric enzymatic methods (Roche/Hitachi, Germany) on a Hitachi 902 automatic chemistry analyzer (Hitachi LTD, Tokyo, Japan). Low-density lipoprotein cholesterol (LDL-C) was calculated with the Friedewald formula modified by DeLong et al. ${ }^{27}$, and non$\mathrm{HDL}$ cholesterol was calculated with the difference between TC minus HDL-C (non-HDL cholesterol = TC - HDL-C).

Insulin concentration was determined by radioimmunoassay (Millipore, St. Charles, Missouri, USA) and insulin resistance was estimated with the HOMA-IR homeostatic model (HOMA-IR = insulin [ulU/mL] x glucose $[\mathrm{mmoL}] / 22.5)^{28}$.

The presence of dyslipidemia was defined, according to the National Cholesterol Education Program Adult Treatment Panel III (NCEP-ATP III) criteria ${ }^{1}$, as hypercholesterolemia (TC $\geq 200$ or LDL-C $\geq 160 \mathrm{mg} / \mathrm{dL}$ ), hypertriglyceridemia ( $\mathrm{TG} \geq 150 \mathrm{mg} / \mathrm{dL}$ ) and hypoalphalipoproteinemia (HDL-C $<40 \mathrm{mg} / \mathrm{dL}$ in men and $<$ $50 \mathrm{mg} / \mathrm{dL}$ in women). Precision and accuracy in the lipid and lipoprotein measurements were periodically certified with the Lipid Standardization Program of the Center for Disease Control and Prevention (LSP-CDC, Atlanta, GA, USA). Intra- and inter-analysis coefficients of variation were $<3 \%$.

$\mathrm{L} p(\mathrm{a})$ concentration was determined by kinetic immunonephelometry with the $\mathrm{N}$ Latex $\mathrm{Lp}(\mathrm{a})$ reagent (Siemens Healthcare Diagnostics Products $\mathrm{GmbH}$,
Marburg, Germany) $)^{29}$ on a BN ProSpec ${ }^{\circledR}$ automated nephelometer, with calibrators, controls and reagents of the same brand. Intra- and inter-analysis coefficients of variation were $<6 \%$.

MetS was defined according to the NCEP-ATP III guidelines ${ }^{1}$ if the participant had at least three of the following five components: 1) waist circumference $\geq 90 \mathrm{~cm}$ in men or $\geq 80 \mathrm{~cm}$ in women; 2) $\mathrm{TG}$ $\geq 150 \mathrm{mg} / \mathrm{dL}$; 3) HDL-C $<40 \mathrm{mg} / \mathrm{dL}$ in men and $<50 \mathrm{mg} / \mathrm{dL}$ in women; 4) systolic blood pressure $\geq 130 \mathrm{mmHg}$ and diastolic $\geq 85 \mathrm{mmHg}$, or antihypertensive pharmacological treatment; and 5) fasting plasma glucose $\geq 126 \mathrm{mg} / \mathrm{dL}$, or previous diabetes mellitus diagnosis or treatment.

\section{Tomographic determinations}

Computed tomography is a validated method for the measurement of visceral adipose tissue and $\mathrm{CAC}^{30}$. In this study, chest and abdomen tomography was performed using a 64-channel multi-detector helical system (Somatom Cardiac Sensation 64, Forchheim, Bavaria, Germany) and was interpreted by experienced radiologists. The tomographic images were evaluated to quantify total, abdominal subcutaneous and visceral adipose tissue ${ }^{31,32}$. Coronary artery calcium buildup is expressed in Agatston units $(\mathrm{AU})^{33}$. All areas with $>130$-Hounsfield units attenuation were considered, and with the sum of the coronary arteries individual scores, total Agatston score was obtained. Intra-observer correlation coefficient was $0.99(p<0.001)$.

\section{Statistical analysis}

Data are expressed as the average and standard deviation or as the median with interquartile range (IQR) for variables with asymmetric distribution, while categorical variables are presented as percentages. Continuous variables were compared using Student's t-test or Mann-Whitney's U-test, depending on the type of distribution. Categorical variables were compared with the chi-square test.

Coronary artery calcium buildup was analyzed as a categorical variable (presence or absence of CAC >0 $A U$. To investigate the independence of associations between $L p(a) \geq 30 \mathrm{mg} / \mathrm{dL}$, MetS and presence of CAC $>0 \mathrm{AU}$, a multiple regression analysis was performed adjusting for gender and age, and then adjusting for BMI, TG, LDL-C, diabetes mellitus, hypertension and smoking. A $p$-value $<0.05$ was considered to be 
Table 1. Subjects' characteristics according to the presence or not of metabolic syndrome

\begin{tabular}{|c|c|c|c|}
\hline & No MetS ( $n=555$ ) & MetS $(n=398)$ & $\mathbf{p}$ \\
\hline Age, years* & $52.7 \pm 9.6$ & $54.1 \pm 8.8$ & 0.006 \\
\hline Males (\%) & 52.1 & 47.9 & $<0.001$ \\
\hline BMI, $\mathrm{kg} / \mathrm{m}^{2 *}$ & $27.3 \pm 4.1$ & $29.9 \pm 4.1$ & $<0.001$ \\
\hline Waist, $\mathrm{cm}^{*}$ & $90.7 \pm 11.3$ & $98.7 \pm 10.4$ & $<0.001$ \\
\hline AVF, $\mathrm{mm}^{3 *}$ & $138.2 \pm 60.8$ & $182.3 \pm 61.1$ & $<0.001$ \\
\hline $\mathrm{ASF}, \mathrm{mm}^{3 *}$ & $112.3 \pm 14.4$ & $123.7 \pm 19.0$ & $<0.001$ \\
\hline $\mathrm{SBP}, \mathrm{mmHg}^{*}$ & $112.3 \pm 14.4$ & $123.7 \pm 19.0$ & $<0.001$ \\
\hline $\mathrm{DBP}, \mathrm{mmHg} *$ & $69.8 \pm 8.3$ & $75.4 \pm 9.8$ & $<0.001$ \\
\hline $\mathrm{TC}, \mathrm{mg} / \mathrm{dL}^{*}$ & $188.8 \pm 32.9$ & $199.2 \pm 40.0$ & $<0.001$ \\
\hline LDL-C, mg/dL* & $115.0 . \pm 28.3$ & $123.7 \pm 35.1$ & 0.003 \\
\hline $\mathrm{TG}, \mathrm{mg} / \mathrm{dL}^{*}$ & $130.9 \pm 58.8$ & $236.2 \pm 193.7$ & $<0.001$ \\
\hline $\mathrm{HDL}-\mathrm{C}, \mathrm{mg} / \mathrm{dL}^{*}$ & $51.5 \pm 13.0$ & $38.5 \pm 9.6$ & $<0.001$ \\
\hline Glucose, $\mathrm{mg} / \mathrm{dL}^{\dagger}$ & $88(82-93)$ & $96.5(88-109.2)$ & $<0.001$ \\
\hline Insulin, $\mu \mathrm{IU} / \mathrm{mL}^{\dagger}$ & $14.4(10.6-19.9)$ & $20.5(15.6-27.1)$ & $<0.001$ \\
\hline HOMA-IR ${ }^{\dagger}$ & $3.1(2.2-4.4)$ & $5.3(3.8-7.6)$ & $<0.001$ \\
\hline $\mathrm{Lp}(\mathrm{a}), \mathrm{mg} / \mathrm{dL}^{\dagger}$ & $5.9(2.5-13.1)$ & $3.7(2.3-9.2)$ & $<0.001$ \\
\hline CAC, AUt & $0.0(0.0-0.0)$ & $0.0(0.0-11.3)$ & $<0.001$ \\
\hline $\mathrm{Lp}(\mathrm{a}) \geq 30 \mathrm{mg} / \mathrm{dL}(\%)$ & 10.8 & 7.5 & 0.087 \\
\hline $\mathrm{CAC}>0 \mathrm{AU}(\%)$ & 23.6 & 39.9 & $<0.001$ \\
\hline ASCVD risk (\% at 10 years $)^{\dagger}$ & $1.2(0.8-2.0)$ & $1.6(1-3.2)$ & $<0.001$ \\
\hline
\end{tabular}

ASCVD: Atherosclerotic cardiovascular disease; CAC: coronary artery calcification; HDL-C: high-density lipoprotein cholesterol; LDL-C: Iow-density lipoprotein cholesterol; TC: total cholesterol; AVF: abdominal visceral fat; ASF: abdominal subcutaneous fat; HOMA-IR: insulin resistance; BMI: body mass index; DBP: diastolic blood pressure; SBP: systolic blood pressure; MetS: metabolic syndrome; TG: triglycerides.

*Average \pm standard deviation.

${ }^{\dagger}$ Median (interquartile range).

statistically significant. All statistical analyses were performed with SPSS V.16.

\section{Results}

The characteristics of the 953 subjects without and with MetS are shown in table 1. Three hundred and ninety-eight participants $(41.7 \%)$ were diagnosed with MetS. In the subjects with MetS, average or median anthropometric variables, such as BMI, waist circumference, abdominal visceral and subcutaneous fat volume, and biochemical variables, such as lipid, lipoprotein, glucose and insulin concentrations, and insulin resistance index (HOMA-IR), were significantly higher than in those without MetS, while HDL-C average was significantly lower $(p<0.001)$ (Table 1).

Median Lp(a) was significantly lower in subjects with MetS: 3.7 (IQR: 2.3-9.2) vs. 5.9 (IQR: 2.5-13.1); $p<0.001$. Compared to subjects without MetS, the prevalence of $L p(a) \geq 30 \mathrm{mg} / \mathrm{dL}$ was lower in subjects with MetS ( 7.5 vs. $10.8 \% ; p=0.087$ ). However, the prevalence of subclinical atherosclerosis (CAC $>0 \mathrm{AU})$ in subjects without MetS was significantly lower than in subjects with MetS (23.6 vs. $39.9 \% ; p<0.001)$ (Table 1).

As shown in figure 1 , the prevalence of $L p(a)$ $\geq 30 \mathrm{mg} / \mathrm{dL}$ is inversely associated, and the prevalence of CAC is positively associated with the number of MetS components. The percentage of subjects with 


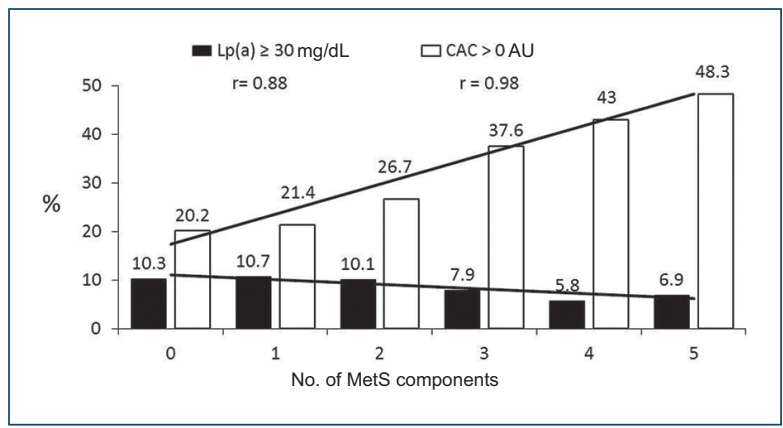

Figure 1. Prevalence of lipoprotein(a) $[\mathrm{Lp}(\mathrm{a})] \geq 30 \mathrm{mg} / \mathrm{dL}$ and coronary artery calcification (CAC) $>0 \mathrm{AU}$ in a Mexican population according to the number of metabolic syndrome (MetS) components.

high $L p(a)$ decreased, and that of individuals with CAC $>0 \mathrm{AU}$ did progressively increase with the presence of one to all five MetS components. These relationships were evaluated with logistic regression analysis to investigate the independence of the association between MetS components and a $\mathrm{Lp}(\mathrm{a})$ concentration $\geq 30 \mathrm{mg} /$ $\mathrm{dL}$ and the presence of $\mathrm{CAC}>0 \mathrm{AU}$. In subjects with MetS with blood glucose $\geq 100 \mathrm{mg} / \mathrm{dL}$ or blood pressure $\geq 130 / 85 \mathrm{mmHg}$, the risk of CAC >0 AU was twice higher than in subjects without MetS (odds ratio [OR]: 2.19, 95\% confidence interval [CI]: 1.6-2.6, $\mathrm{p}<0.001$; OR: 2.4, 95\% Cl: 1.7-3.4, p < 0.001; and OR: 2.1, $95 \%$ Cl: 1.6-3.1, $p<0.001$; respectively). TG $\geq 150 \mathrm{mg} / \mathrm{dL}, \mathrm{HDL}-\mathrm{C}$ low concentration $(<50 \mathrm{mg} / \mathrm{dL}$ in women and $<40 \mathrm{mg} / \mathrm{dL}$ in men) and obesity (waist circumference) were not associated with higher risk of $\mathrm{CAC}>0 \mathrm{AU}$ (Fig. 2).

\section{Discussion}

$L p(a)$ is an independent risk factor for $C A D^{34}$; however, the degree of association with atherosclerosis broadly varies between different ethnic groups. In this cross-sectional study in 953 Mexicans with no personal or family history of premature CAD, $L p(a) \geq 30 \mathrm{mg} /$ $\mathrm{dL}$ median and prevalence were significantly lower in subjects with MetS, while the prevalence of CAC $>0$ $A U$ was significantly higher. The prevalence of CAC > $0 \mathrm{AU}$ progressively increased, with the presence of one to five MetS components. However, the percentage of subjects with elevated $L p(a)$ decreased and was not associated with CAC. Body adiposity measurements, such as BMI and abdominal visceral and subcutaneous fat, and cardiometabolic markers such as plasma insulin and HOMA-IR, were significantly

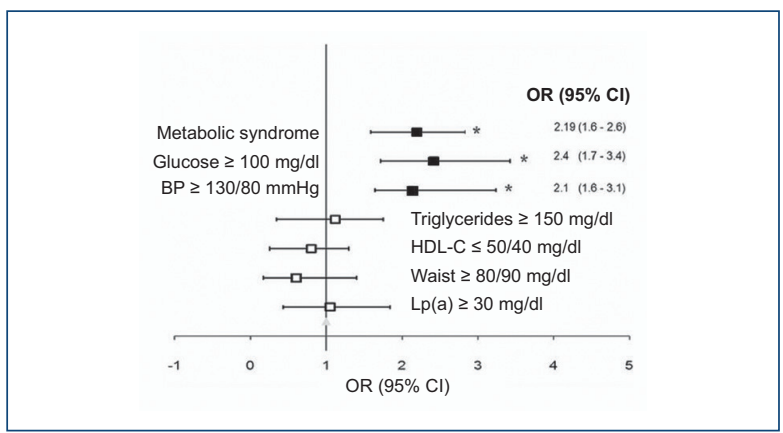

Figure 2. Risk of subclinical atherosclerosis (coronary artery calcification $>0 \mathrm{AU}$ ) in subjects with metabolic syndrome and its components in a Mexican population. Multiple regression analysis adjusted for gender, age, low-density lipoprotein cholesterol, smoking and physical activity. HDL-C: high-density lipoprotein cholesterol; $\mathrm{Cl}$ : confidence interval; OR: odds ratio; BP: blood pressure.

higher in subjects with MetS, but blood glucose > $100 \mathrm{mg} / \mathrm{dL}$ and hypertension $>130 / 85 \mathrm{mmHg}$ were the only MetS components that were independently and significantly associated with the presence of subclinical atherosclerosis.

The 2014 ATP III consensus ${ }^{35}$ suggests that the first therapeutic target for the treatment of atherosclerosis is LDL-C elevated concentration, and the next one should be MetS, because each one of its components is a risk factor for CAD. $L p(a)$ elevated concentration is an emerging risk factor for $C A D^{13-36,37}$. It has been suggested that the coexistence of elevated $L p(a)$ with MetS could potentiate the risk of premature atherosclerosis or accelerate the atherosclerotic process ${ }^{38}$; however, studies where this association has been investigated are scarce and the results are controversial. In the vast majority of studies, each one of the MetS components and their association with $L p(a)$ concentration are analyzed separately. In patients with heart conditions with and without MetS, those who had MetS were found to have $L p(a)$ concentrations 1.8 times higher than those without MetS (median, 29.2 vs. $16.2 \mathrm{mg} / \mathrm{dL} ; \mathrm{p}<0.0001$ ) and a prevalence 2.3 times higher of $L p(a) \geq 30 \mathrm{mg} /$ $\mathrm{dL}(51.4 \text { vs. } 21.6 \% ; p<0.001)^{39}$. In another study, Lp(a) mean concentrations $(5-17 \mathrm{mg} / \mathrm{dL})$ in women, in comparison with men with MetS, were found to be associated with atherosclerosis progression ${ }^{38}$. However, Lp(a) concentrations have been reported to be significantly lower in patients with MetS in comparison with subjects without MetS, with $L p(a)$ showing to be a predictor of cardiovascular events in subjects without MetS ${ }^{40}$; furthermore, in subjects with higher $L p(a)$ concentration, 
the risk of MetS has been documented to be significantly lower ${ }^{41}$. These authors suggest that the inverse relationship between MetS and $L p(a)$ could be due to a survival bias in subjects with a history of CAD. The presence of $L p(a) \geq 30 \mathrm{mg} / \mathrm{dL}$ and MetS at early ages might increase mortality in young subjects, which would explain the higher proportion of low Lp(a) among survivors of older age ${ }^{41}$.

Our data in subjects without CAD, grouped by age decades, showed that, from 20 to 70 years, the prevalence of elevated $L p(a)$ is higher in subjects without MetS, and, therefore, this does not support the hypothesis of a survival effect that tries to explain the inverse relationship between both these risk factors for CAD; in fact, the prevalence of $L p(a) \geq 30 \mathrm{mg} / \mathrm{dL}$ is not associated with MetS or subclinical atherosclerosis at any age range. Similar results have been reported by other researchers ${ }^{42}$.

In other studies that included patients with $C A D^{43}$ or with dyslipidemias ${ }^{44}$, an inverse association has been observed between $L p(a)$ concentrations and elevated TG and low HDL-C. The authors suggest that the association could be due to a shared metabolic mechanism between these three biochemical factors. In the present study, a negative and significant correlation between TG and $L p(a)$ was observed $(r=-0.073 ; p=$ 0.024), which was lost when the sample was grouped in subjects with and without MetS. These results confirm the findings reported in another study ${ }^{45}$ and support the results, in vitro, where $L p(a)$ is shown to be a ligand for the very-low density lipoprotein receptor in endothelial cell membranes, in macrophages, foamy cells and smooth muscle cells in atherosclerotic plaques. Lp(a) internalization into these cells could significantly contribute to $L p(a)$ catabolism and to the development of atherosclerotic plaques ${ }^{46}$. It is well documented that $L p(a)$ decreases the effects of PAI- 1 and plasmin formation, which generates a pro-thrombotic state. In subjects with MetS, there are hemostatic alterations that decrease fibrinolysis and favor coagulation ${ }^{47}$. It has been suggested that PAl-1 increased concentration in subjects with MetS could decrease Lp(a) synthesis ${ }^{48,49}$. The pathophysiological mechanism of the relationship between MetS, $L p(a)$ and atherosclerosis is unknown; however, a prospective study in subjects with MetS and elevated $L p(a)$ could generate information that allows knowing, at least in part, the relationship between these cardiovascular risk factors.

This study has as limitations that it is of the cross-sectional type, and thus only associations between variables can be established, and it is not possible for causality to be established. The study included volunteers who were residents of Mexico City's metropolitan area and the sample is not representative of the Mexican population; however, the prevalence of the CAD risk factors that were observed in this study is similar to that found in the 2016 National Survey on Health and Nutrition (ENSANUT MC 2016), a nation-wide randomized and representative study ${ }^{50}$. The strengths of the study include the sample size (larger than in other studies), the fact that the study subjects are of both genders, with ages ranging from 20 to 70 years and with no presence of personal or family history of atherosclerosis, which reduces bias in interpretation of results, and subclinical atherosclerosis (CAC) evaluation in the entire sample.

\section{Conclusions}

This study in an asymptomatic Mexican population without a history of coronary artery disease found: 1) an inverse association between $L p(a)$ concentration and MetS and its components; 2) an elevated Lp(a) concentration in subjects with MetS is not associated with subclinical atherosclerosis due to CAC; and 3) the high prevalence of overweight, obesity, diabetes mellitus, high blood pressure and atherogenic dyslipidemia (high TG and low HDL-C) that characterizes the Mexican population could explain the differences with other populations.

\section{Acknowledgements}

The authors would like to thank the study subjects, as well as the staff who participated in the Genética de la Enfermedad Aterosclerótica (GEA) project.

\section{Funding}

This work was partially supported by Consejo Nacional de Ciencia y Tecnología (CONACyT Fronteras de la Ciencia No. 2016-01-1958).

\section{Conflicts of interest}

None.

\section{Ethical disclosures}

Protection of human and animal subjects. The authors declare that the procedures that were followed 
adhered to the ethical standards of the responsible committee for experimentation on human beings and were in agreement with the World Medical Association and the Declaration of Helsinki.

Confidentiality of data. The authors declare that they have followed the protocols of their work center on the publication of patient data.

Right to privacy and informed consent. The authors have obtained informed consent from the patients and/or subjects referred to in the article. This document is in the possession of the corresponding author.

\section{References}

1. Third Report of the National Cholesterol Education Program (NCEP) Expert Panel on Detection, Evaluation, and Treatment of High Blood Cholesterol in Adults (Adult Treatment Panel III) final report. Circulation. 2002;106:3143-21.

2. Saely $\mathrm{CH}$, Aczel S, Marte T, Langer P, Hoefle G, Drexel H, et al. The metabolic syndrome, insulin resistance, and cardiovascular risk in diabetic and nondiabetic patients. J Clin Endocrinol Metab. 2005;90:5698-703.

3. Galassi A, Reynolds K, He J. Metabolic syndrome and risk of cardiovascular disease: a meta-analysis. Am J Med. 2006;119:812-9.

4. Lu J, Wang L, Li M, Xu Y, Jiang Y, Wang W, et al. Metabolic syndrome among adults in China: The 2010 China Non Communicable Disease Surveillance. J Clin Endocrinol Metab. 2017;102:507-15.

5. McLean JW, Tomlinson JE, Kuang WJ, Eaton DL, Chen EY, Fless GM, et al. cDNA sequence of human apolipoprotein(a) is homologous to plasminogen. Nature. 1987;330:132-7.

6. Rouy D, Grailhe P, Nigon F, Chapman J, Anglés-Cano E. Lipoprotein(a) impairs generation of plasmin by fibrin-bound tissue-type plasminogen activator. In vitro studies in a plasma milieu. Arterioscler Thromb. 1991;11:629-38.

7. Hervio L, Chapman MJ, Thillet J, Loyau S, Anglés-Cano E. Does apolipoprotein(a) heterogeneity influence lipoprotein(a) effects on fibrinolysis? Blood. 1993;82:392-7.

8. Clarke R, Peden JF, Hopewell JC, Kyriakou T, Goel A, Heath SC, et al. Genetic variants associated with $L p(a)$ lipoprotein level and coronary disease. N Engl J Med. 2009;361:2518-28.

9. Kamstrup PR, Tybjaerg-Hansen A, Steffensen R, Nordestgaard BG. Genetically elevated lipoprotein(a) and increased risk of myocardial infarction. JAMA. 2009;301:2331-9.

10. Tsimikas S, Hall JL. Lipoprotein(a) as a potential causal genetic risk factor of cardiovascular disease: a rationale for increased efforts to understand its pathophysiology and develop targeted therapies. J Am Coll Cardiol. 2012;60:716-21.

11. Nordestgaard BG, Chapman MJ, Ray K, Borén J, Andreotti F, Watts GF et al. Lipoprotein(a) as a cardiovascular risk factor: current status. Eur Heart J. 2010;31:2844-53.

12. Dubé JB, Boffa MB, Hegele RA, Koschinsky ML. Lipoprotein(a): more interesting than ever after 50 years. Curr Opin Lipidol. 2012;23:133-40.

13. Danesh J, Collins R, Peto R. Lipoprotein(a) and coronary heart disease. Meta-analysis of prospective studies. Circulation. 2000;102:1082-5.

14. Superko HR, Hecht HS. Metabolic disorders contribute to subclinical coronary atherosclerosis in patients with coronary calcification. Am J Cardiol. 2001;88:260-4.

15. Verweij SL, de Ronde MWJ, Verbeek R, Boekholdt SM, Planken RN Stroes ESG, et al. Elevated lipoprotein(a) levels are associated with coronary artery calcium scores in asymptomatic individuals with a family history of premature atherosclerotic cardiovascular disease. J Clin Lipidol. 2018;12:597-603.

16. Mahoney LT, Burns TL, Stanford W, Thompson BH, Witt JD, Rost CA et al. Coronary risk factors measured in childhood and young adult life are associated with coronary artery calcification in young adults: the Muscatine Study. J Am Coll Cardiol. 1996;27:277-84.

17. Nishino M, Malloy MJ, Naya-Vigne J, Russell J, Kane JP, Redberg RF. Lack of association of lipoprotein(a) levels with coronary calcium deposits in asymptomatic postmenopausal women. J Am Coll Cardiol. 2000;35:314-20.

18. Sharrett AR, Ballantyne CM, Coady SA, Heiss G, Sorlie PD, Catellier D, et al. Coronary heart disease prediction from lipoprotein cholesterol levels, triglycerides, lipoprotein(a), apolipoproteins $A-I$ and $B$, and HDL density subfractions: The Atherosclerosis Risk in Communities (ARIC) Study. Circulation. 2001;104:110813.
19. Qasim AN, Martin SS, Mehta NN, Wolfe ML, Park J, Schwartz S, et al Lipoprotein(a) is strongly associated with coronary artery calcification in type-2 diabetic women. Int J Cardiol. 2011;150:17-21.

20. Shai I, Schulze MB, Manson JE, Stampfer MJ, Rifai N, Hu FB. A prospective study of lipoprotein(a) and risk of coronary heart disease among women with type 2 diabetes. Diabetologia. 2005;48:1469-76.

21. Cardoso-Saldana G, Ize-Lema I, Kimura LY, Zamora González J, Posadas Romero C. Lipoprotein(a) and cardiovascular risk in adult Mexicans. Rev Invest Clin. 1997;49:85-92.

22. Budoff MJ, Shaw LJ, Liu ST, Weinstein SR, Mosler TP, Tseng PH, et al. Long-term prognosis associated with coronary calcification: observations from a registry of 25,253 patients. J Am Coll Cardiol. 2007;49:1860-70.

23. Posadas-Romero C, López-Bautista F, Rodas-Díaz MA, Posadas-Sánchez R, Kimura-Hayama E, Juárez-Rojas JG, et al. Prevalence and extent of coronary artery calcification in an asymptomatic cardiovascular Mexican population: Genetics of Atherosclerotic Disease study. Arch Cardiol Mex. 2017;87:292-301.

24. Villarreal-Molina $T$, Posadas-Romero $C$, Romero-Hidalgo S, Antúnez-Argüelles E, Bautista-Grande A, Vargas-Alarcón G, et al. The ABCA1 gene $\mathrm{R} 230 \mathrm{C}$ variant is associated with decreased risk of premature coronary artery disease: the Genetics of Atherosclerotic Disease (GEA) Study. PLoS One. 2012;7:e49285.

25. Chobanian AV, Bakris GL, Black HR, Cushman WC, Green LA, Izzo JL Jr, et al. The Seventh Report of the Joint National Committee on Prevention, Detection, Evaluation, and Treatment of High Blood Pressure: the JNC 7 report. JAMA. 2003;289:2560-72.

26. Baecke JA, Burema J, Frijters JE. A short questionnaire for the measurement of habitual physical activity in epidemiological studies. Am J Clin Nutr. 1982;36:936-42.

27. DeLong DM, DeLong ER, Wood PD, Lippel K, Rifkind BM. A comparison of methods for the estimation of plasma low- and very low-density lipoprotein cholesterol. The Lipid Research Clinics Prevalence Study. JAMA. 1986;256:2372-7.

28. Matthews D, Hosker J, Rudenski A, Naylor BA, Treacher DF, Turner RC. Homeostasis model assessment: insulin resistance and [-cell function from fasting plasma glucose and insulin concentrations in man. Diabetologia. 1985;28:412-9.

29. Marcovina SM, Albers JJ, Scanu AM, Kennedy H, Giaculli F, Berg K, et al. Use of a reference material proposed by the International Federation of Clinical Chemistry and Laboratory Medicine to evaluate analytical methods for the determination of plasma lipoprotein(a). Clin Chem. 2000:46:1956-67.

30. Maurovich-Horvat P, Massaro J, Fox CS, Moselewski F, O'Donnell CJ Hoffmann U. Comparison of anthropometric, area- and volume-based assessment of abdominal subcutaneous and visceral adipose tissue volumes using multi-detector computed tomography. Int J Obes. 2007; 31:500-6.

31. Kvist H, Chowdhury B, Grangard U, Tylén U, Sjöström L. Total and visceral adipose-tissue volumes derived from measurements with computed tomography in adult men and women: predictive equations. Am J Clin Nutr. 1988;48:1351-61.

32. Armellini F, Zamboni M, Castelli S, Micciolo R, Mino A, Turcato E, et al. Measured and predicted total and visceral adipose tissue in women. Correlations with metabolic parameters. Int J Obes Relat Metab Disord. 1994;18:641-7.

33. Mautner GC, Mautner SL, Froehlich J, Feuerstein IM, Proschan MA Roberts WC, et al. Coronary artery calcification: assessment with electron beam CT and histomorphometric correlation. Radiology. 1994;192:619-23.

34. Nordestgaard BG, Chapman MJ, Ray K, Borén J, Andreotti F, Watts GF, et al. Lipoprotein(a) as a cardiovascular risk factor: current status. Eur Heart J. 2010;31:2844-53.

35. Eckel RH, Cornier M-A. Update on the NCEP ATP-III emerging cardiometabolic risk factors. BMC Med. 2014;12:115.

36. Craig WY, Neveux LM, Palomaki GE, Cleveland MM, Haddow JE. Lipoprotein(a) as a risk factor for ischemic heart disease: metaanalysis of prospective studies. Clin Chem. 1998;44:2301-6.

37. Luc G, Bard J-M, Arveiler D, Ferrieres J, Evans A, Amouyel P, et al. Lipoprotein (a) as a predictor of coronary heart disease: the PRIME Study. Atherosclerosis. 2002;163:377-84.

38. Onat A, Hergenc G, Ozhan H, Kaya Z, Bulur S, Ayhan E, et al. Lipoprotein (a) is associated with coronary heart disease independent of metabolic syndrome. Coron Artery Dis. 2008;19:125-31.

39. Bozbas H, Yildirir A, Pirat B, Eroğlu S, Korkmaz ME, Atar I, et al. Increased lipoprotein(a) in metabolic syndrome: is it a contributing factor to premature atherosclerosis? Anadolu Kardiyol Derg. 2008;8:111-5.

40. Vonbank A, Saely CH, Rein P, Zanolin D, Drexel H. Lipoprotein(a), the metabolic syndrome and vascular risk in angiographied coronary patients. $\mathrm{J}$ Clin Endocrinol Metab. 2016;101:3199-203.

41. Wu XY, Lin L, Qi HY, Du R, Hu CY, Ma LN, et al. Association between lipoprotein(a) levels and metabolic syndrome in a middle-aged and elderly Chinese cohort. Biomed Environ Sci. 2019;32:477-85. 
42. Sung K, Wild SH, Byrne CD. Lipoprotein(a), metabolic syndrome and coronary calcium score in a large occupational cohort. Nutr Metab Cardiovasc Dis. 2013;23:1239-46.

43. Konerman M, Kulkarni K, Toth PP, Jones SR. Evidence of dependence of lipoprotein(a) on triglyceride and high-density lipoprotein metabolism. J Clin Lipidol. 2012;6:27-32.

44. Werba JP, Safa O, Gianfranceschi G, Michelagnoli S, Sirtori CR, Franceschini G. Plasma triglycerides and lipoprotein(a): inverse relationship in a hyperlipidemic Italian population. Atherosclerosis. 1993;101:203-11.

45. Bartens W, Rader DJ, Talley G, Brewer HB Jr. Decreased plasma levels of lipoprotein(a) in patients with hypertriglyceridemia. Atherosclerosis. 1994;108:147-9

46. Argraves KMT, Kozarsky KF, Fallon JT, Harpel PC, Strickland DK. The atherogenic lipoprotein $\mathrm{Lp}(\mathrm{a})$ is internalized and degraded in a process mediated by the VLDL receptor. J Clin Invest. 1997;100:2170-81.
47. von Depka $M$, Nowak-Göttl $U$, Eisert $R$, Dieterich $C$, Barthels $M$, Scharrer I, et al. Increased lipoprotein (a) levels as an independent risk factor for venous thromboembolism. Blood. 2000;96:3364-8.

48. Srikanthan K, Feyh A, Visweshwar H, Shapiro JI, Sodhi K. Systematic review of metabolic syndrome biomarkers: a panel for early detection, management, and risk stratification in the West Virginian population. Int J Med Sci. 2016;13:25-38.

49. Kostapanos MS, Florentin M, Elisaf MS, Mikhailidis DP. Hemostatic factors and the metabolic syndrome. Curr Vasc Pharmacol. 2013;11:880-905.

50. Rangel-BaltazarE, Cuevas-Nasu L, Shamah-Levy T, Rodríguez-Ramírez S, Méndez-Gómez-Humarán I, Rivera JA. Association between high waistto-height ratio and cardiovascular risk among adults sampled by the 2016 half-way National Health and Nutrition Survey in Mexico (ENSANUT MC 2016). Nutrients. 2019;11:1402. 